BIP: Jurnal Bahasa Indonesia Prima

Vol. 3, No. 2, 2021, September 2021, PP.

\title{
PENGEMBANGAN INSTRUMEN PENILAIAN BERBASIS KEMAMPUAN BERPIKIR TINGKAT TINGGI (HOTS) UNTUK PEMBELAJARAN TEKS RESENSI
}

\author{
Zira Fatmaira ${ }^{1}$, Tioria Pasaribu ${ }^{2}$ \\ Program Studi Sistem Informasi \\ Sekolah Tinggi Manajemen Informatika dan Komputer Kaputama \\ Corresponding Author: zirafatmaira0301@gmail.com
}

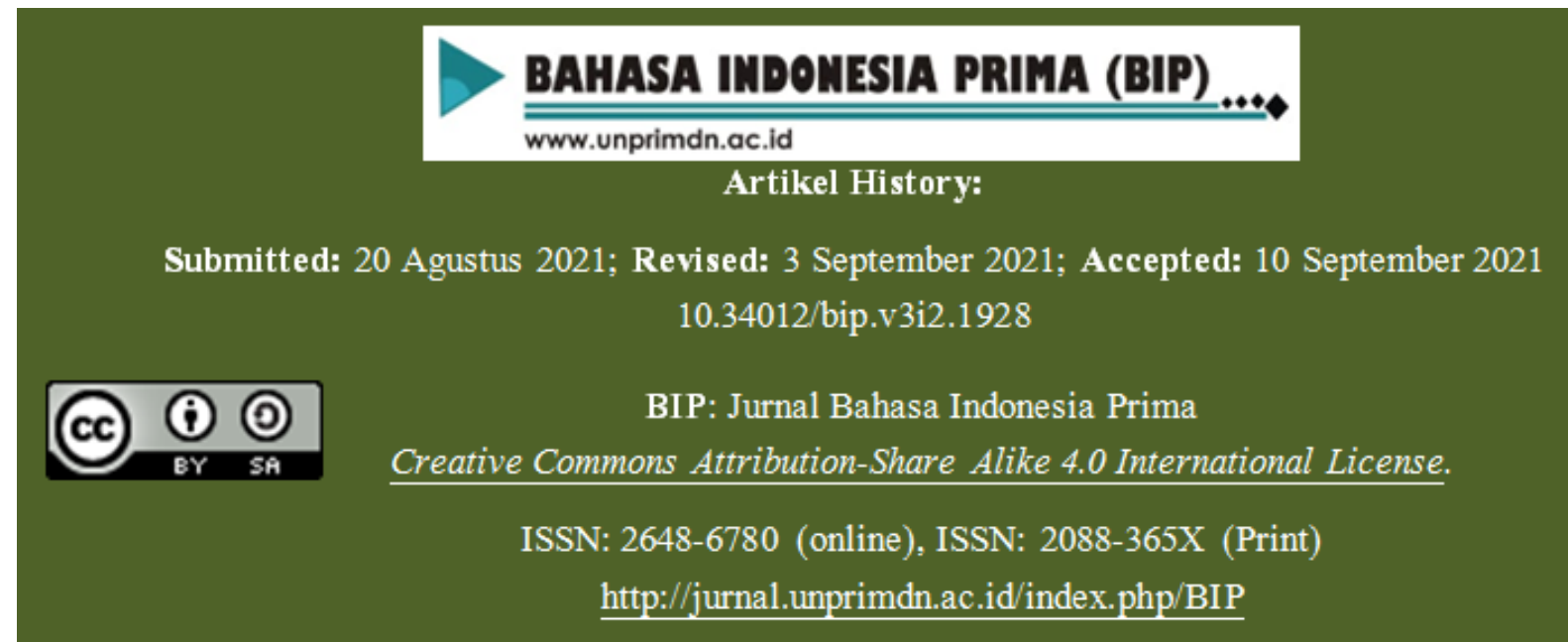

Abstrak-Pengembangan instrumen Penilaian soal tes pada materi teks resensi dengan berbasis kemampuan berpikir tingkat tinggi (HOTS) sangat dibutuhkan untuk mengukur tingkat kemampuan siswa dalam meningkatkan pengetahuan pada materi teks resensi. Tetapi pada kenyataannya guru masih belum sepenuhnya mengembangkan instrumen penilaian berbasis kemampuan berpikir tingkat tinggi (HOTS). Selain itu belum tersedianya instrumen assessment yang didesain khusus untuk melatih HOTS atau keterampilan berpikir tingkat tinggi peserta didik. Karena peserta didik yang mempunyai kemampuan berpikir tingkat tinggi jika tidak diberikan kesempatan untuk mengembangkan dan tidak diarahkan dengan tepat maka kemampuan berpikirnya tidak akan meningkat. Bagi peserta didik yang cenderung berpikir tingkat rendah perlu dilatih sejak dasar, agar pada saat memasuki jenjang pendidikan berikutnya peserta didik tidak merasa takut jika dihadapkan pada pertanyaan atau permasalahan yang lebih rumit. Masalah dalam pembahasan ini didapat dari hasil wawancara yang diajukan kepada beberapa guru di Mas Al-Asy'ari Medan Krio. Salah satu cara dalam menerapkan kemampuan berpikir tingkat tinggi (HOTS) adalah dengan melakukan penilaian berupa tes tertulis. Dan pada pembahasan ini secara khusus membahas tentang Pengembangan Instrumen Penilaian Berbasis Kemampuan Berpikir Tingkat Tinggi (HOTS) Untuk Pembelajaran Teks Resensi.

Kata kunci:teks resensi, HOTS

Abstract-Development of an instrument for assessing test items based on high order thinking skills (HOTS) is needed to measure the level of students' ability to increase knowledge of review text material. But in reality, teachers still have not fully developed an assessment instrument based on higher order thinking skills (HOTS). In addition, there is no assessment 
instrument specifically designed to train HOTS or students' higher-order thinking skills. Because students who have higher-order thinking skills if they are not given the opportunity to develop and are not directed properly, their thinking skills will not increase. For students who tend to think at a lower level, they need to be trained from the ground up, so that when they enter the next level of education, students do not feel afraid if they are faced with more complicated questions or problems. The problem in this discussion was obtained from the results of interviews submitted to several teachers at Mas Al-Asy'ari Medan Krio. One way to apply higher order thinking skills (HOTS) is to conduct an assessment in the form of a written test. And in this discussion specifically discusses the Development of Assessment Instruments Based on Higher Order Thinking Skills (HOTS) for Studying Review Texts.

Keywords: review text, HOTS

\section{A. Pendahuluan}

Pembelajaran bahasa Indonesia sekarang memiliki nilai KKM yang membuat siswa harus mendapat kan nilai yang lebih tinggi untuk menuntaskan pembelajaran bahasa indonesia, sebagian siswa masih banyak mengalami kesulitan dalam mencapai ketuntasan nilai bahasa Indonesia. Siswa dituntut untuk mampu dalam menyelesaikan pembelajaran bahasa Indonesia salah satu nya dalam membuat teks resensi. Teks resensi merupakan tulisan yang berisi kupasan atau ulasan terhadap sebuah buku. Resensi merupakan sikap menilai sebuah buku, baik itu kelebihannya maupun kekurangannya baik buku berjenis fiksi maupun nonfiksi. Penilaian tersebut dapat dilakukan mulai dari bagian luar hingga dalam buku, seperti identitas buku dan isi buku. Teks resensi merupakan jenis tulisan yang berisi ulasan/pertimbangan/rangkuman tentang sebuah buku yang dipelajari oleh siswa kelas XI SMA.

Instrumen penilaian memberikan konstribusi yang sangat berarti dalam proses pembelajaran. Hal ini juga tidak terlepas dari kegiatan pembelajaran guru dan siswa di dalam kelas. Melalui penerapan beberapa model pembelajaran di kelas dapat menjadi peluang bagi guru untuk menerapkan kegiatan pembelajaran pada tingkat HOTS (High Order Thinking Skill). Dalam penyusunan instrumen penilaian, guru hendaknya mendesain tes dalam pembelajaran secara kolaboratif untuk melatih kemampuan kerjasama, kemampuan berkomunikasi, kemampuan berargumentasi serta kemampuan mengendalikan emosi. Pada implementasinya, penerapan HOTS bukanlah hal yang mudah untuk dilaksanakan guru. Kemampuan guru dalam menyusun skenario pembelajaran dan instrumen penilaian berbasis kemampuan berpikir tingkat tinggi (HOTS) harus sama-sama ditingkatkan.

Penyusunan instrumen penilaian berbasis kemampuan berpikir tingkat tinggi (HOTS) adalah hal yang baik, tetapi hal ini harus diawali dengan pembelajaran kemampuan berpikir tingkat tinggi (HOTS) juga. Tetapi pada kenyataannya guru masih belum sepenuhnya mengembangkan instrumen penilaian berbasis kemampuan berpikir tingkat tinggi (HOTS). Selain itu belum tersedianya instrumen assessment yang didesain khusus untuk melatih HOTS atau keterampilan berpikir tingkat tinggi peserta didik. Karena peserta didik yang mempunyai kemampuan berpikir tingkat tinggi jika tidak diberikan kesempatan untuk mengembangkan dan tidak 
BIP: Jurnal Bahasa Indonesia Prima Vol. 3, No. 2, 2021, September 2021, PP.

diarahkan dengan tepat maka kemampuan berpikirnya tidak akan meningkat. Bagi peserta didik yang cenderung berpikir tingkat rendah perlu dilatih sejak dasar, agar pada saat memasuki jenjang pendidikan berikutnya peserta didik tidak merasa takut jika dihadapkan pada pertanyaan atau permasalahan yang lebih rumit. Masalah dalam pembahasan ini didapat dari hasil wawancara yang diajukan kepada beberapa guru di Mas AlAsy'ari Medan Krio.

Salah satu cara dalam menerapkan kemampuan berpikir tingkat tinggi (HOTS) adalah dengan melakukan penilaian berupa tes tertulis. Pengembangan instrumen Penilaian soal tes pada materi teks resensi dengan berbasis kemampuan berpikir tingkat tinggi sangat dibutuhkan untuk mengukur tingkat kemampuan siswa dalam meningkatkan pengetahuan pada materi teks resensi. Pengembangan instrumen penilaian ini juga sangat dibutuhkan dalam mendukung kemajuan hasil belajar siswa dalam materi teks resensi. Instrumen penilaian ini dikembangkan dengan berbasis kemampuan berpikir tingkat tinggi (HOTS), metode ini akanberfungsi sebagai ciri khas dari soal-soal tes yang dikembangkan. Dan pada pembahasan ini secara khusus membahas tentang Pengembangan Instrumen Penilaian Berbasis Kemampuan Berpikir Tingkat Tinggi (HOTS) Untuk Pembelajaran Teks Resensi.

Adapun rumusan masalah dalam penelitian ini adalah sebagai berikut.

1. Bagaimanakah proses pengembangan instrumen penilaian teks resensi berbasis kemampuan berpikir tingkat tinggi (HOTS)?

2. Bagaimana merancang instrumen penilaian teks resensi berbasis kemampuan berpikir tingkat tinggi (HOTS)?

3. Bagaimanakah hasil uji coba instrumen penilaian teks resensi berbasis kemampuan berpikir tingkat tinggi (HOTS)?

Tujuan penelitian adalah sebagai berikut.

1. Untuk mengetahui proses pengembangan instrumen penilaian teks resensi berbasis kemampuan berpikir tingkat tinggi (HOTS).

2. Untuk merancang instrumen penilaian teks resensi berbasis kemampuan berpikir tingkat tinggi (HOTS).

3. Untuk mengetahui hasil uji coba instrumen penilaian teks resensi berbasis kemampuan berpikir tingkat tinggi (HOTS).

\section{Urgensi (Keutamaan) Penelitian}

Penelitian ini sangat penting dilakukan, karena intrumen pembelajaran mendukung para gurusarana peningkatanhasil belajar siswa di Sekolah Menengah Atas pada materi pembelajaran teks resensi dan dapat membantu guru-guru dalam memberikan penilaian pembelajaran, khususnya dalam pelajaran Bahasa Indonesia.

\section{B. Tinjauan Pustaka}

Resensi merupakan suatu istilah untuk menilai sebuah buku yang dibaca, buku tersebut dapat dilihat dari segi kelebihan dan kelemahan yang ada pada sebuah buku. Menurut kamus besar bahasa indonesia (KBBI) adalah pertimbangan atau pembicaraan tentang buku, ulasan buku. Selain itu, Dalman (2014:229) menyatakan bahwa resensi adalah sebuah istilah digunakan untuk menilai baik tidaknya sebuah buku. Dalam hal ini yang dinilai adalah keunggulan dan kelemahan buku (baik fisik maupun nonfisik) sehingga orang merasa terpersuasif setelah membacanya. Berdasarkan pendapat ahli tersebut dapat disimpulkan bahwa resensi 
merupakan sebuah ulasan atau menilai sebuah hasil karya sastra seorang penulis yang dapat di komentari dari hasil tulisan yang $d$ baca oleh si penulis resensi buku tersebut.

Dalman (2012:167) menyatakan bahwa tujuan merensi sebuah buku antara lain:

1. Memberikan informasi atau pemahaman yang komprehensif tentang apa yang tampak dan terungkap dalam sebuah buku.

2. Mengajak pembaca untuk memikirkan, merenungkan, dan mendiskusikan lebih jauh fenomena atau problem yang muncul dalam sebuah buku.

3. Memberikan pertimbangan kepada pembaca apakah sebuah buku pantas mendapat smbutan dari masyarakat atau tidak.

4. Menjawab pertanyaan yang timbul jika seseorang melihat buku yang baru terbit seperti : siapa pengarangnya, mengapa yang baru terbit itu, bagaimana hubungannya dengan bukubuku sejenis karya pengarang yang sama, dan bagaimana hubungannya dengan buku sejenis karya pengarang lain.

Unsur-unsur yang harus diperhatikan dalam meresensi sebuah buku. Sudaryanto (2008:11) menjelaskan beberapa unsurunsur dalam meresensi sebuah buku yaitu :

1. Identitas buku; mencakup judul buku , judul asli buku (jika buku terjemahan ), pengarangan, editor, penerjemah, penerbit, kota penerbit, tahun terbit, cetakan terbit, dan tebal buku meliputi bagian pengantar dan inti serta indeks.

2. Judul resensi ; mencakup isi tulisan atau inti tulisan, biasanya dibuat sesudah resensi selesai ditulis dan tidak lebih dari enam kata.
3. Gambar umum isi buku; mencakup hal-hal yang ingin disampaikan penulis buku secara umum.

4. Hasil analisis kelebihan dan kekurangan buku; mencakup hal-hal yang dinilai sebagai kelebihan dan kekurangan buku melalui proses perbandingan dengan karya penulis yang sama atau dengan buku yang bertema sejenis yang ditulis oleh penulis lain.

5. Ciri- ciri bahasa yang digunakan oleh penulis buku; mencakup penggunaan bahasa dalam sebuah buku, apakah berjenis ilmiah akademik, ilmiah populer, atau reflektif.

6. Manfaat yang diperoleh pembaca; mencakup manfaat teoretis dan praktis dari buku yang dibaca dan diresensi. Bisa jadi, suatu resensi akan menarik dan dimuat dimedia massa jika dalam tulisan tersebut telah dituliskan manfaat nyata bagi para pembaca buku.

Langkah-langkah membuat resensi adalah :

1. Penjajakan atau pengenalan terhadap buku yang akan diresensi.

2. Membaca buku yang akan diresensi secara komprehensif, cermat, dan teliti.

3. Menandai bagian-bagian buku yang diperhatikan secara khusu dan menentukan bagian-bagian yang dikutip untuk dijadikan data.

4. Membuat sinopsis atau intisari dari buku yang diresensi.

5. Menentukan sikap dan menilai hal-hal yang berkenaan dengan organisasi penulisan, bobot ide, aspek bahasanya, dan aspek teknisnya.

\section{High Order Thinking Skill (HOTS)}

Saputra (2016:92) mengatakan bahwaberpikir tingkat tinggi adalah peningkatan kemampuan pemahaman dan 
penguasaan anak didik atas materi pembelajaran agar ia dapat berpikir secara kritis (critical thinking), kreatif (creative thinking), mampu memecahkan maslah (problem solving), dan mampu membuat putusan (making decision) dalam situasisituasi yang sulit. Dengan demikian, kemampuan berpikir tingkat tinggi (Higher Order Thingking skill) meliputi kemampuan menulis resensi dalam menganalisis, mengevaluasi, dan menciptakan.

Higher Order Thinking Skills yang dalam bahasa Indonesia dikenal sebagai kemampuan berpikir tingkat tinggi. Sastrawati (2011:6) menyatakan bahwa berpikir tingkat tinggi adalah proses yang melibatkan operasi-operasi mental seperti klasifikasi, induksi, deduksi, dan penalaran. Dalam proses berpikir tingkat tinggi seringkali dihadapkan dengan banyak ketidakpastian dan juga menuntut beragam aplikasi yang terkadang bertentangan dengan kriteria yang telah ditemukan dalam proses evaluasi.

Konsep utama dari HOTS ini adalah bagaimana caranya meningkatkan kemampuan berfikir tingkat tinggi peserta didik yang berfikir secara kritis dan kreatif dalam memecahkan suatu masalah yang dihadapinya. Krulik dan Rudnick (dalam Saputra. 2016:92) menyatakan bahwa:

Problem solving is a Process. It is the means by wich an individual uses previously acquired knowledge, skills, understending to satisry the demands of an unfamiliar situasion. The process begins with the initial confrontation and conludes when an answer has been obtained and considered with regard to the initial confrontation and considered with regard to the initial conditions. The student must synthesize what he or she has learned, and apply it to the new and different situation.

Pemecahan masalah merupakan suatu proses individu dalam pengetahuan dan keterampilan untuk memecahakan masalah yang ada disekitar, proses pemacahan masalah tersebut dapat melatih siswa dalam cara berfikir tingkat siswa yang dengan melalui cara berfikir kritis dsn kreatif siswa, maka peserta didik dapat memecahkan masalah nya dengan cara berpikir tingkat tinggi mereka.

\section{Metode Penelitian}

\section{Desain Penelitian}

Peneliti menggunakan model penelitian pengembangan berdasarkan model Brog dan Gall dengan alasan rancangan pengembangan tersebut digunakan untuk mengembangkan suatu produk yang dapat dihasilkan. Jenis penelitian ini adalah Reseasrch and Deveplomend $(R \& D)$. Selanjutnya, Sugiyono (2010:407) menyatakan bahwa penelitian dan pengembangan adalah metode penelitian yang digunakan untuk menghasilkan produk tertentu dan menguji keefektifan produk tertentu. Selain itu, Putra (2012:67) menyatakan bahwa $R \& D$ merupakan metode penelitian yang secara sengaja, sistematis bertujuan/diarahkan untuk mencari temukan, merumuskan, memperbaiki, mengembangkan, menghasilkan, menguji keefektifan produk, model, metode/strategi/cara, jasa prosedur tertentu yang lebih unggul, baru, efektif, efisien, produktif, dan bermakna.

\section{Ruang Lingkup Penelitian}

Penelitian ini akan dilaksanakan di MAS Al- Asy'ari Medan Krio Sumatera Utara pada masa pandemik Covid 19 tahun 2021. 


\section{Kerangka Kerja Penelitian}

Deskripsi tentang prosedur dan langkah-langkah penelitian pengembangan yang dikemukakan oleh Borg \& Gall (2003:224) menyatakan bahwa prosedur penelitian pengembangan pada dasarnya terdiri dari dua tujuan utama, yaitu: (1) mengembangkan produk, dan (2) menguji keefektifan produk dalam mencapai tujuan.

Metode penelitian adalah gambaran langkah-langkah agar penelitian dapat dilakukan dengan tersetruktur. Langkah yang dilakukan mulai dari mempelajari masalah sampai dapat menghasilakan suatu sistem sehingga masalah dapat teratasi. Maka akan ditetapkan beberapa tahapan yang dilakukan, untuk lebih lengkapnya disajikan pada gambar 1 dibawah ini :

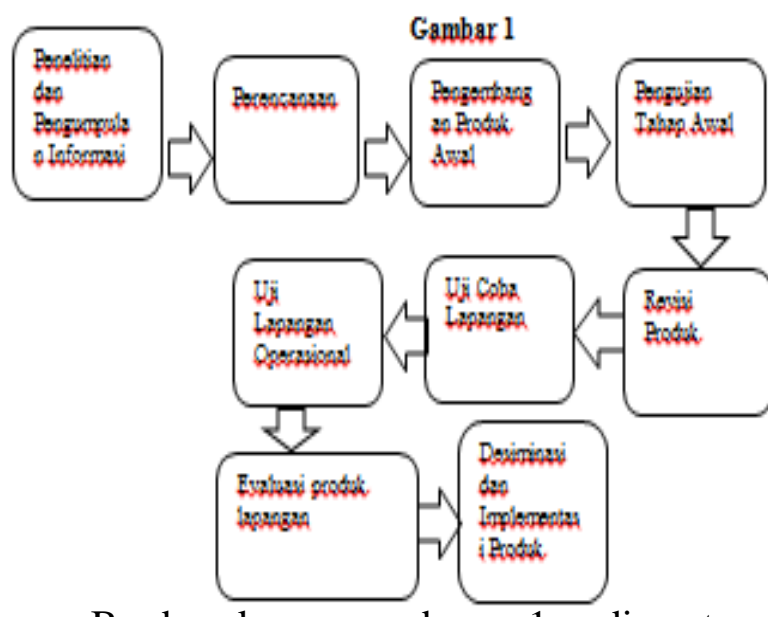

Berdasarkan gambar 1 di atas selanjutnya dapat dikemukakan penjelasan sebagai berikut :

1. Penelitian dan pengumpulan informasi (Research and information collecting); termasuk dalam langkah ini antara lain studi literatur yang berkaitan dengan permasalahan yang dikaji, dan persiapan untuk merumuskan kerangka kerja penelitian.

2. Perencanaan(Planning;) termasuk dalam langkah ini merumuskan kecakapan dan keahlian yang berkaitan dengan permasalahan, menentukan tujuan yang akan dicapai pada setiap tahapan, dan jika mungkin/diperlukan melaksanakan studi kelayakan secara terbatas.

3. Pengembangan Produk Awal (Develop preminary form of product), yaitu mengembangkan bentuk permulaan dari produk yang akan dihasilkan. Termasuk dalam langkah ini adalah persiapan komponen pendukung, menyiapkan pedoman dan buku petunjuk, dan melakukan evaluasi terhadap kelayakan alat-alat pendukung.

4. Pengujian Tahap Awal(Preminary field testing), yaitu melakukan ujicoba lapangan awal dalam skala terbatas dengan melibatkan subjek sebanyak 3 subjek. Pada langkah ini pengumpulan dan analisis data dapat dilakukan dengan cara wawancara, observasi atau angket.

5. Revisi Produk (Main product revision), yaitu melakukan perbaikan terhadap produk awal yang dihasilkan berdasarkan hasil ujicoba awal. Perbaikan ini sangat mungkin dilakukan lebih dari satu kali, sesuai dengan hasil yang ditunjukkan dalam ujicoba terbatas, sehingga diperoleh draft produk utama yang siap diujicoba lebih luas.

6. Uji Coba Lapangan (Main field testing), uji coba utama yang melibatkan seluruh siswa.

7. Uji Lapangan Oprasional(Operational field testing), yaitu langkah uji validasi terhadap model operasional yang telah dihasilkan.

8. Evaluasi Produk Lapangan (Operational product evaluation), yaitu melakukan 
perbaikan/penyempurnaan terhadap

hasil uji coba lebih luas, sehingga produk yang dikembangkan sudah merupakan desain model operasional yang siap divalidasi.

\section{Analisis}

Analisis, merupakan proses mengidentifikasi masalah pada tempat yang dijadikan sampel penelitian. Dalam penelitian ini langkah analisis merupakan tahap pengumpulan data terkait permasalahan yang terjadi dalam pembelajaran yang kemudian diidentifikasi pemecahan masalahnya melalui analisis kebutuhan yang sesuai dengan permasalahan yang ditemukan. Permasalahan yang ditemukan dalam penelitian ini adalah minat belajar siswa rendah, dan pemecahan masalahnya dengan mengembangkan model pembelajaran Berpikir tingkat Tinggi (HOTS)

\section{Prosedur Penelitian}

\section{Tahap Pra Lapangan}

Tahap ini dilakukan untuk mengetahui kondisi awal lokasi tempat yang dijadikan sebagai lokasi penelitian, sebagai observasi tahap awal. Setelah observasi dilakukan langkah selanjutnya adalah pembuatan proposal dan instrumen penelitian yang dikonsultasikan dengan dosen pembimbing terlebih dahulu

\section{Tahap Pelaksanaan}

Tahap dalam pelaksanaan Penelitian dan pengembangan instrumen penilaian berbasis HOTS untuk materi pembelajaran menulis teks resensi yang digunakan dalam penelitian merupakan modefikasi dari metode penelitian Research \& Development (R\&D) dari sugiyono yang disesuaikan dengan langkah-langkah pengembangan instrumen penilaian. Tahap pelaksanaan penelitian pengembangan instrumen penilaian berbasis HOTS pada materi resensi sebagai berikut:

1) Penelitian dan pengumpulan informasi (kajian pustaka, Kompetensi Inti (KI) dan Kompetensi Dasar (KD), dan mengidentifkasi masalah);

2) Perencanaan pengembangan Instrumen penilaian berbasis kemampuan berpikir tingkat tinggi (HOTS) pada materi teks resensi untuk siswa kelas XI MAS Al-Asy'ari Medan Krio;

3) Mengembangkan bentuk pendahuluan produk instrumen penilaian teks resensi berbasis kemampuan berpikir tingkat tinggi (HOTS);

4) Uji lapangan awal (validasi ahli);

5) Revisi I terhadap produk utama berdasarkan saran validator ahli;

6) Uji Coba perorangan (angket kelompok perorangan oleh 3 orang siswa dengan karakteristik kemampuan tinggi, sedang, dan rendah); angket penilaian diberikan pada pemakai secara perorangan dengan tujuan mengetahui kesahihan produk setelah diperbaiki berdasarkan tinjauan yang terdiri dari tiga siswa. Masukan-masukan dari uji coba perorangan ini selanjutnya digunakan sebagai dasar dalam melakukan perbaikan-perbaikan terhadap produk.

7) Revisi II terhadap produk bila membutuhkan revisi; Uji coba kelompok kecil (9 orang siswa), dengan menggunakan angket. Apabila terdapat kekurangan-kekurangan yang perlu diperbaiki dari produk yang dikembangkan maka akan dilakukan revisi;

8) Revisi III dari hasil uji coba kelompok kecil bila perlu; Uji coba kelompok lapangan terbatas (40 siswa) yaitu 
kelas XI MAS Al-Asy'ari Medan Krio dengan menggunakan angket.

9) Revisi IV terhadap produk bila masih ada, menganalisis dan mengolah data, membuat simpulan;

10) Produk akhir pengembangan instrume penilaian berbasis kemampuan berpikir tingkat tinggi (HOTS) pada materi teks resensi yaitu soal-soal tes yang telah dikembangkan dan siap diterapkan pada kegiatan pembelajaran teks resensi guna membantu siswa untuk meningkatkan pemahaman materi yang diajarkan. Adapun langkah-langkah pengembangan Instrumen penilaian berbasis kemampuan berpikir tingkat tinggi (HOTS) pada materi teks resensi.

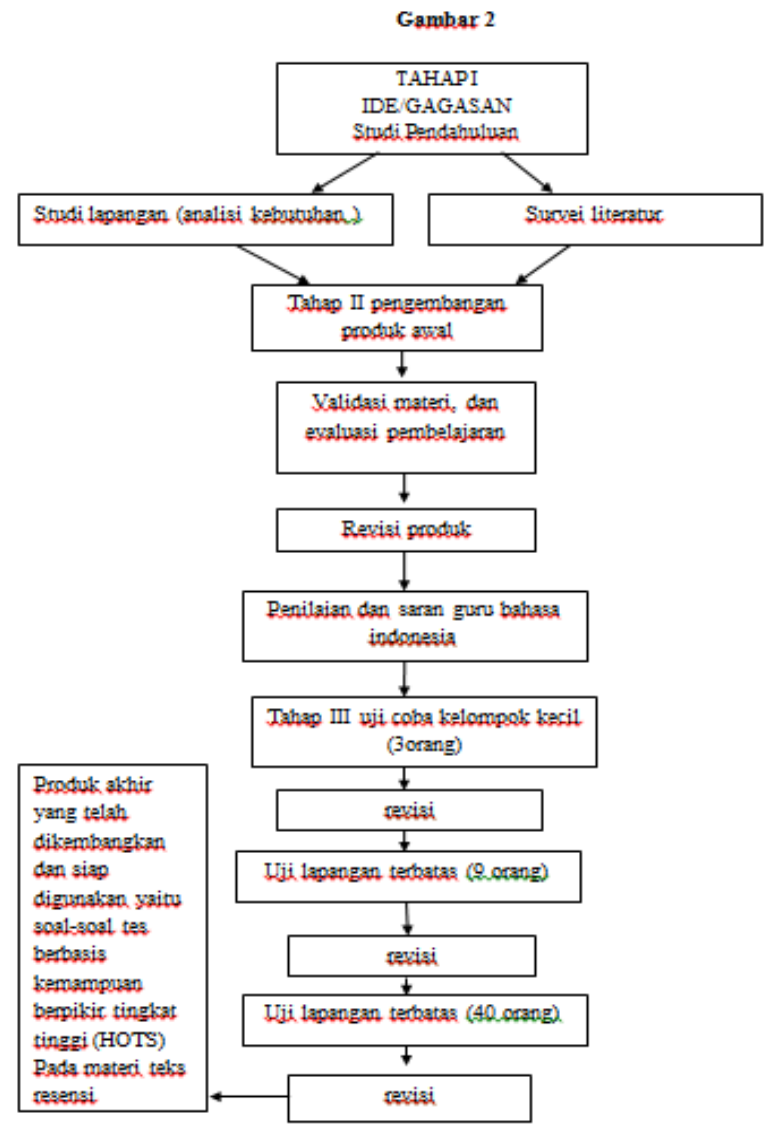

\section{Tahap Pelaksanaan}

Tahap ini merupakan tahap penerapan Instreumen penilaian berpikir tingkat tinggi (HOTS) Pada pembelajaran Teks
Resensi yang telah dikembangkan oleh peneliti dalam upaya meningkatkan Hasil belajar siswa. Selain itu juga mengumpulkan data yang diperlukan melalui metode pengumpulan data yang telah ditetapkan sebelumnya.

\section{Tahap Analisis}

Tahap ini merupakan tahan pengolahan data yang telah dikumpulkan selama penelitian agar dapat disusun menjadi sebuah laporan utuh.

\section{Hasil dan Pembahasan Penyusunan Tes}

Tes yang disusun dalam penelitian ini adalah tes yang terdapat pada instrumen penilaian berbasis HOTS berbentuk pilihan berganda (multiple choise) dan uraian. Hal ini dilakukan untuk melihat kemampuan berpikir siswa tingkat tinggi. Tes disusun berdasarkan spesifikasi tujuan pembelajaran dan indikator yang diukur.

\section{Pemilihan Media}

Media pembelajaran yang digunakan dalam pelaksanaan pembelajaran menggunakan koran, majalah yang menerbitkan teks resensi dan instrumen penilaian berbasis HOTS pada materi teks resensi di kelas XI MAS Al-Asy'ari Medan Krio. Media yang digunakan merupakan media visual (buku). Di dalam instrumen penilaian disajikan materi serta soal-soal yang melatih kemampuan berpikir tingkat tinggi siswa.

\section{Pemilihan Format}

Pemilihan format pengembangan instrumen penilaian ini bertujuan untuk mendesain atau merancang isi pembelajaran, pemilihan strategi, pendekatan, metode pembelajaran, sumber belajar dan tatacara penilaian itu sendiri. Format yang dipilih adalah yang memenuhi kriteria menarik dan memudahkan. Pemilihan format dilakukan dengan mengkaji format-format dari 
BIP: Jurnal Bahasa Indonesia Prima Vol. 3, No. 2, 2021, September 2021, PP.

pedoman

menulisinstrumen

penilaianberbasis HOTS yang telah ada. Adapun format dalam penelitian ini diadopsi dari pedoman menulisinstrumen penilaianberbasis HOTS yang relevan.

\section{Pengembangan Produk Awal}

Pada tahap ini dilakukan pembuatan instrumen penilaianberbasis HOTS, yaitu; 1) Membuat story board. Story board dibuat dengan tujuan mempermudah dalam pembuatan instrumen penilaianberbasis HOTS dan untuk menentukan tahap pengembangan selanjutnya, agar bagian-bagian dari media pembelajaran dapat tersusun dengan baik. Story board dibuat dengan cara menggambar sketsa di atas kertas, sketsa yang telah selesai dibuat lalu digambar ulang menggunakan komputer. 2) Story board lalu dijadikan acuan membuat layout. Layout dibuat dengan memperhatikan aspek warna dan komposisi; 3) Layout yang telah selesai dibuat lalu diisi dengan kegiatan. Kegiatan di dalam instrumen penilaianberbasis HOTS ini terdiri dari 2 kegiatan yaitu, kegiatan 1 berisi pemetaan $\mathrm{KI}, \mathrm{KD}$ dan indikator, materi, serta 15 soal pilihan berganda (multiple choise) dan 5 soal uraian. Kegiatan 2 berisi pemetaan KI, KD dan indikator, materi, serta 10 soal pilihan berganda (multiple choise) dan 5 soal uraian serta penskoran, kunci jawaban, glosarium dan daftar pustaka. Adapun deskripsi dari produk instrumen penilaian berbasis HOTS materi teks resensi di MAS Al-Asy'ari Medan Krio sebagai berikut :

\section{a. Identitas Produk}

Bahan Fisik: Bahan Cetak (material printed)

Judul: Panduan Instrumen PenilaianTeks Resensi Berbasis HOTS

Materi: Teks Resensi
Sasaran: Siswa Kelas XI MAS AlAsy'ariMedan Krio

Nama Pengarang: Zira Fatmaira, M. Pd;

Tioria Pasaribu, M. Pd

Tebal Halaman : 98 Halaman

Cetakan : Pertama

Kertas : A5 (210mm x 148mm)

\section{Sampul Buku}

Bagian sampul buku dengan materi teks resensi memiliki bagian depan dan belakang. Berikut penjelasannya :

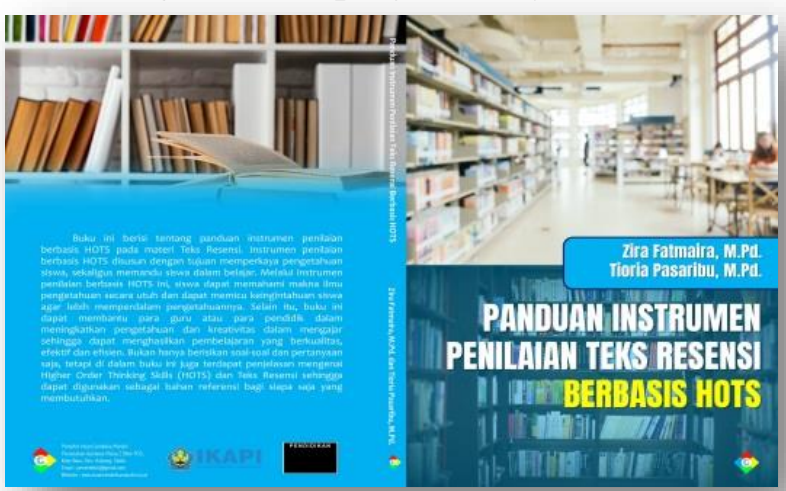

\section{Gambar 3 Cover Depan dan Belakang}

Cover depan bahan ajar terdiri dari nama penyusun, judul instrumen penilaian disesuaikan dengan materi yang dikembangkan. Backround di sesuaikan dengan penilaian yang ada di dalam buku, terdapat tabel, diagram dan catatan, terlihat juga buku yang di resensi, hal ini dimaksudkan agar pembaca mampu mengetahui makna judul dan ilustrasi tersebut sebelum membuka isi instrumen penilaian.

\section{Prakata}

\section{Gambar 4 Prakata}

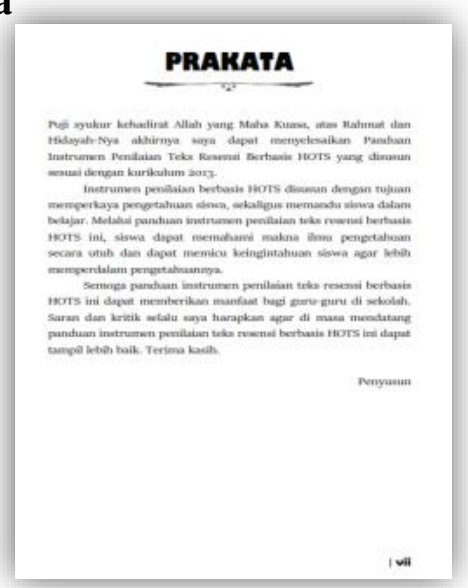

Pengembangan Instrumen Penilaian Berbasis Kemampuan Berpikir 
Kata pengantar ditempatkan pada halaman awal buku sebagai pembuka komunikasi penulis dengan pembaca. Isi dari kata pengantar adalah upaya penulis untuk berkomunikasi dengan pembaca, dengan menerapkan beberapa jenis prinsip, yaitu: 1) memberikan kesan bahwa instrumen penilaian disusun layak dan penting untuk dibaca dan dipelajari, 2) Keunggulan isi disajikan dalam instrumen penilaian, 3) Harapan penulis yang berkaitan dengan prospek terhadap pendidikan dan kesempurnaan instrumen penialaian.

\section{Daftar Isi}

Daftar isi mencakup tentang isi dari materi teks resensi yang ada dalam buku panduan instrumen penilaian.

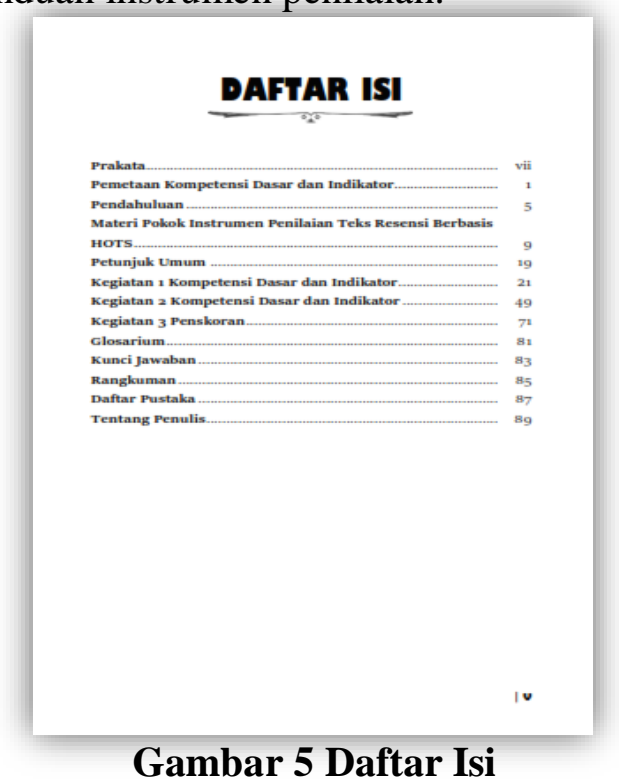

4. Kegiatan Pembelajaran

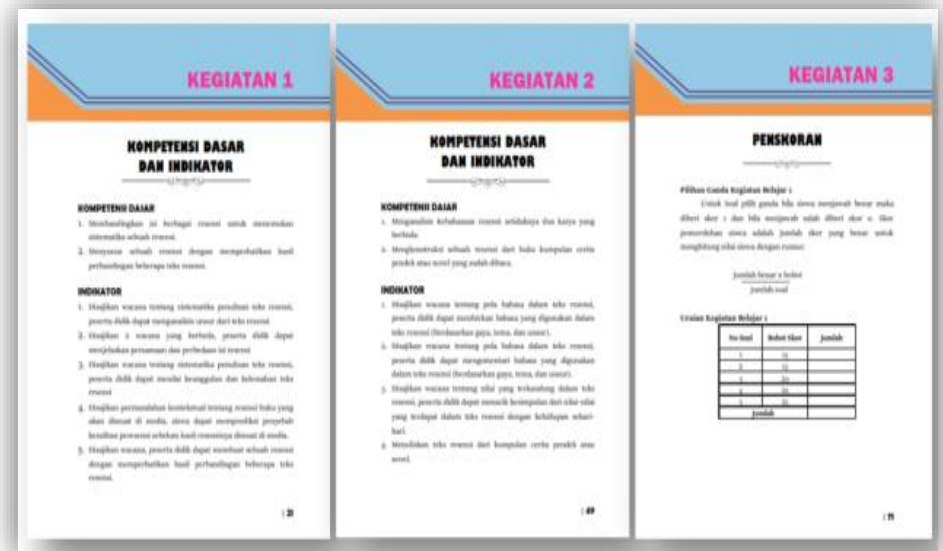

Gambar 6 Kegiatan Pembelajaran
Materi pembelajaran berisi materi yang sudah ditentukan sesuai dengan KI, KD, Indikator dan tujuan pembelajaran dengan harapan guru dan siswa dapat mengetahui hasil yang diperoleh.

\section{Daftar Pustaka}

Daftar pustaka berisi referensi bahan bacaan yang relevan dengan materi teks resensi yang ada dalam instrumen penilaian.

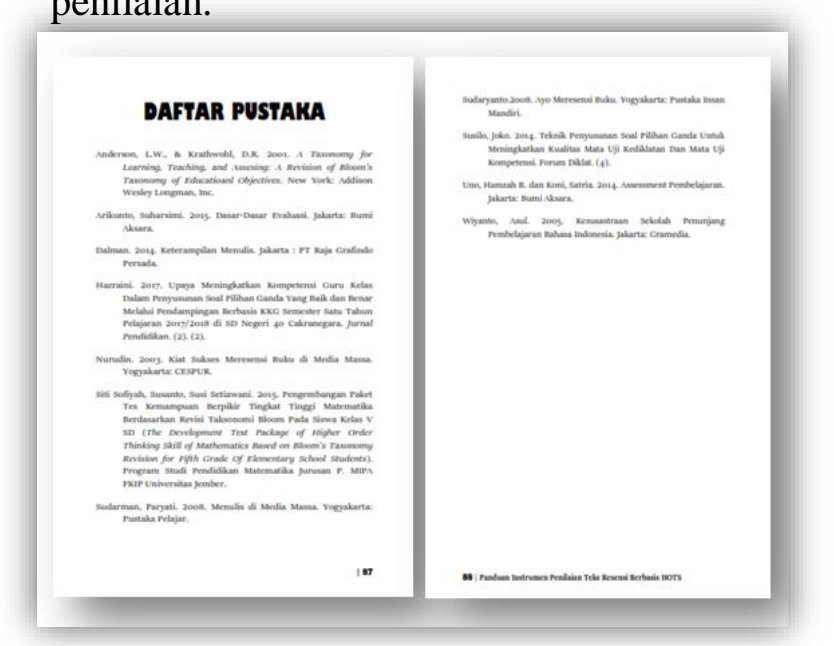

\section{Gambar 7 Daftar Pustaka}

\section{Simpulan}

Berdasarkan hasil penelitian dan pembahasan yang telah diuraikan dalam penelitian ini, maka dapat disimpulkan sebagai berikut:

1. Pengembangan instrumen penilaian teks resensi berbasis kemampuan berpikir tingkat tinggi (HOTS) sangat penting dilakukan guna meningkatkan hasil belajar siswa pada mata pelajaran bahasa Indonesia, khususnya mengenai materi Teks Resensi.

2. Instrumen penilaian teks resensi berbasis kemampuan berpikir tingkat tinggi (HOTS) dirancang dengan melakukan interview/wawancara dengan guru bahasa Indonesia untuk mendapatkan informasi tentang minat dan hasil belajar siswa, melakukan observasi langsung ke siswa, dan mengkonsultasikan soal-soal instrumen penilaian teks resensi berbasis 
BIP: Jurnal Bahasa Indonesia Prima Vol. 3, No. 2, 2021, September 2021, PP.

kemampuan berpikir tingkat tinggi (HOTS) dengan pakar ahli.

3. Hasil uji coba instrumen penilaian teks resensi berbasis kemampuan berpikir tingkat tinggi (HOTS) berhasil meningkatkan minat dan hasil belajar siswa pada mata pelajaran bahasa Indonesia.

\section{Ucapan Terima Kasih}

Kami menyampaikan Terima Kasih yang sebesar-besarnya kepada Kementerian Riset dan Teknologi (KEMENRISTEK)/ Badan Riset dan Inovasi Nasional (BRIN) atas dukungan dan kesempatandalam melaksanakan Penelitian Dosen Pemula (PDP) tahun anggaran 2021. Kami juga mengucapkan Terima Kasih kepada STMIK Kaputama atas dukungan dalam pelaksanaan kegiatan penelitian. Selain itu, tidak lupa juga kami mengucapkan Terima Kasih kepada MASAl-Asy'ari Medan Krio yang telah memberikan waktu, tempat, dan kesempatan dalam melaksanakan kegiatan penelitian ini dengan baik.

\section{Daftar Pustaka}

Anderson, L. W. , \& Krathwohl, D. R. 2001. A Taxonomy for Learning, Teaching, and Assesing: A Revision of Bloom's Taxonomy of Educatioanl Objectives. New York: Addison Wesley Longman, Inc.

Anderson dan Krathwohl. 2010. Kerangka Landasan untuk Pembelajaran, Pengajaran, dan Asesmen. Yogyakarta: Pustaka Pelajar.

Arikunto, Suharsimi. 2011. Dasar-Dasar Evaluasi Pendidikan. Bumi Aksara. Jakarta.
Asrul, Nanda, dan Roshita. 2014. Evaluasi Pembelajaran. Bandung : Cita Pustaka Media.

Basuki Ismed dan Hariyanto. 2014. Asesmen Pembelajaran. Bandung: PT Remaja Rosdakarya.

Direktorat Pembinaan SMA. 2015. Penyusunan soal Higher Orde Thinking Skills's (Sekolah Menengah Atas). Jakarta.

Dalman. 2014. Keterampilan Menulis. Jakarta: PT Raja Grafindo Persada.

Saputra, Hatta. 2016. Pengembangan Mutu Pendidikan Menuju Era Global: Penguatan Mutu Pembelajaran dengan Penerapan HOTS (High Orde Thinking Skills). Bandung : CV Smiles Indonesia Institute.

Sastrawati, E. , Muhammad, R. , \& Syamsurizal. (2011). ProblemBased Learning, Strategi Metakognisi, Dan Keterampilan Berpikir Tingkat Tinggi Siswa. Tekno Pedagogi, 1(2), 1-14.

Sofiyah, Siti, Susanto, Susi Setiawani. 2015. Pengembangan Paket Tes Kemampuan Berpikir Tingkat Tinggi Matematika Berdasarkan Revisi Taksonomi Bloom Pada Siswa Kelas V SD (The Development Test Package of Higher Order Thinking Skill ofMathematics Based on Bloom's Taxonomy Revision forFifth Grade Of Elementary School Students). Program Studi Pendidikan 
BIP: Jurnal Bahasa Indonesia Prima Vol. 3, No. 2, 2021, September 2021, PP.

Matematika Jurusan P. MIPA

FKIP Universitas Jember.

Sudaryanto. 2008. Ayo Meresensi Buku.

Yogyakarta: Pustaka Insan

Mandiri. 